\title{
THE EFFECT OF HERBAL MOUTHWASH (BETEL LEAF) AGAINST HALITOSIS IN ELDERLY
}

\author{
Poetry Oktanauli*, Pinka Taher*, Dyah Munsyi Aulia** \\ ${ }^{*}$ Department of Oral Biology, Faculty of Dentistry, Universitas Prof Dr Moestopo (Beragama), Jakarta \\ ${ }^{* *}$ Faculty of Dentistry, Universitas Prof Dr Moestopo (Beragama), Jakarta \\ Corresponding: poetry@dsn.moestopo.ac.id
}

\begin{abstract}
ABSTRAK
Latar belakang: lansia mengalami penurunan kebersihan mulut, berkurangnya jumlah gigi, menurunnya sensitivitas mukosa mulut, dan xerostomia.Xerostomiadapat menyebabkan menurunnya kebersihan mulutdan mengakibatkan terjadinya peningkatan bau mulut (halitosis). Salah satu terapi halitosis yang dapat dilakukan adalah dengan menggunakan obat kumur.Dari berbagai jenis obat kumur yang terdapat di pasaran, belum diketahui efektivitas dari penggunaan obat kumur herbal terhadap halitosis. Penelitian ini menggunakan obat kumur herbal yang mengandung daun sirih, karena daun sirih memiliki kemampuan antibakteri, antioksidan dan antijamur. Tujuan: penelitian ini bertujuan memberikan informasi tentang manfaat obat kumur herbal pada penurunan skor halitosis pada lansia. Metode: penelitian ini merupakan penelitian eksperimental klinis dengan pendekatan cross sectional. Subjek berjumlah30, diambil dengan cara quota sampling.Pengumpulan data dilakukan dengan mengukur skor halitosis awal dan akhir setelah berkumur dengan obat kumur herbal (daun sirih), menggunakan Tanitabreathchecker. Tanita breath checker adalah monitor seukuran telapak tangan yang dapat mendeteksi dan mengukur keberadaan senyawa volatile sulfur compound (VSC) dengan menampilkan level halitosis. Uji korelasi Spearman digunakan untuk menentukan efek obat kumur herbal pada penurunan skor halitosis. Hasil: terdapat penurunan skor halitosis sebelum dan sesudah berkumur dengan obat kumur herbal (daun sirih). Penurunan signifikan dalam skor halitosis ditunjukkan oleh $\mathrm{p}=$ 0,000. Kesimpulan: penelitian menunjukkan bahwa penurunan skor halitosis disebabkan oleh kandungan minyak atsiri dalam daun sirih. Kandungan terbesar minyak atsiri adalah kavikol dan betlephenol. Kavikol memiliki daya antibakteri lima kali lebih kuat dibandingkan fenol. Dengan demikian, obat kumur herbal (daun sirih) dapat digunakan sebagai terapi alternatif untuk mengatasi halitosis pada lansia.
\end{abstract}

Kata kunci: halitosis, lansia, obat kumur herbal, daun sirih.

\section{ABSTRACT}

Background: elderly generally experience a decreased in oral hygiene, number of teeth, mucosal sensitivity of the oral cavity and xerostomia. Xerostomia can cause the decreased in oral hygiene and cause an increase in bad breath (halitosis). One of halitosis therapy that can be done is by using mouthwash. Of the various types of mouthwash on the market, the effectiveness of herbal mouthwash against halitosis is unknown. This research is using herbal mouthwash containing betel leaves, becauseit has an antibacterial, antioxidant and antifungal ability. Purpose: to give information on the benefits of herbal mouthwash on decreasing halitosis score in elderly. Method: this was a clinical experimental research with cross sectional approach. Spearman correlation test was used to determine the effect of herbal mouthwash on decreasing halitosis scores. The numbers of subject were 30 and obtained by quota sampling. Data collection was done by measuring initial and final halitosis score after rinsing with herbal mouthwash (betel leaf), using Tanita breath checker. Tanita breath checker is an innovative palm-sized monitor that can detect and measure the presence of volatile sulfur compound (VSC) by displaying the level of halitosis. Result: the result showed a decrease in halitosis score before and after rinsing with herbal mouthwash (betel leaf). A significant decrease in the halitosis score is indicated by the $p=0,000$ obtained from the results of the Spearman correlation test. There was a significant decrease in the halitosis score after rinsing with herbal mouthwash. Conclusion: the present study showed that the decrease in halitosis score is due to the betel leaf containing essential oils. The largest content of essential oils is kavikol and betlephenol. Kavikol has an antibacterial power five times stronger than phenol. Thus, herbal mouthwash (betel leaf) can be used as an alternative therapy to overcome halitosis in the elderly.

Keywords: halitosis, elderly, herbal mouthwash, betel leaf. 


\section{BACKGROUND}

$\mathrm{E}$ lderly is a normal stage of development that will be experienced by every individual who reaches old age ${ }^{1}$. Elderly generally experience a decreased in oral hygiene, number of teeth, mucosal sensitivity of the oral cavity and xerostomia. Xerostomia is characterized by the decreased of salivary production and resulting in impaired oral salivary function. One of salivary function in the oral cavity is as self cleansing, thereforexerostomia can cause bad breath, or calledhalitosis. ${ }^{2,3}$ Halitosis in the elderly can be caused by this conditions. Halitosis is an oral health condition characterized by unpleasant odors emanating consistently from the oral cavity. ${ }^{4}$

Halitosis comes from the Latin "halitus" which means breath and the suffix "osis" comes from Greek which means a condition or an abnormal condition. Halitosis or bad breath is one of the dental health problems which is still complained of by most people ${ }^{5}$. Halitosis is caused by volatile sulfur compound (VSC). Volatile sulfur compound(VSC) is a result of the production of bacteria's activity in the oral cavity. ${ }^{6}$

One of the halitosis therapies that can be done is by using mouthwash. Mouthwash is a solution containing breath freshener, astringent, demulent, surfactant and antibacterial to refresh the respiratory tract that is used by rinsing. The active ingredients of the mouthwash formula can be derived from chemicals or natural substances. ${ }^{7}$ Mouthwash based on the active ingredients can be divided into several groups, namely essential oils, trichlosan, bisbiguanides, quaternary ammonia mixture, sanguinarine, povidone iodine, hexetidine and plant extracts. ${ }^{8}$ Mouthwash with herbal ingredients of medicinal plants has been developed because it has antibacterial properties with minimal side effects. Betel leaf is one of the plants, used as traditional medicine. ${ }^{9}$

Research conducted by Suwondoin 1991 states that betel leaf can be used as a source of medicinal ingredients in dentistry. The results of his research showed that betel leaf is one of the 13 types of plants that have the highest antibacterial activity ${ }^{2}$ Nuniek's research in 2012 proved that betel leaf boiled water has antibacterial properties against aerobic and anaerobic bacteria. $^{10}$

Betel leaf is often used to treat halitosis because ithas antibacterial, antioxidant and antifungalproperties. ${ }^{10}$ Betel leaf can be seen in figure $1 .{ }^{11}$ Therefore, the purpose of this study was to give information on the benefits of herbal mouthwash on decreasing halitosis score in elderly.

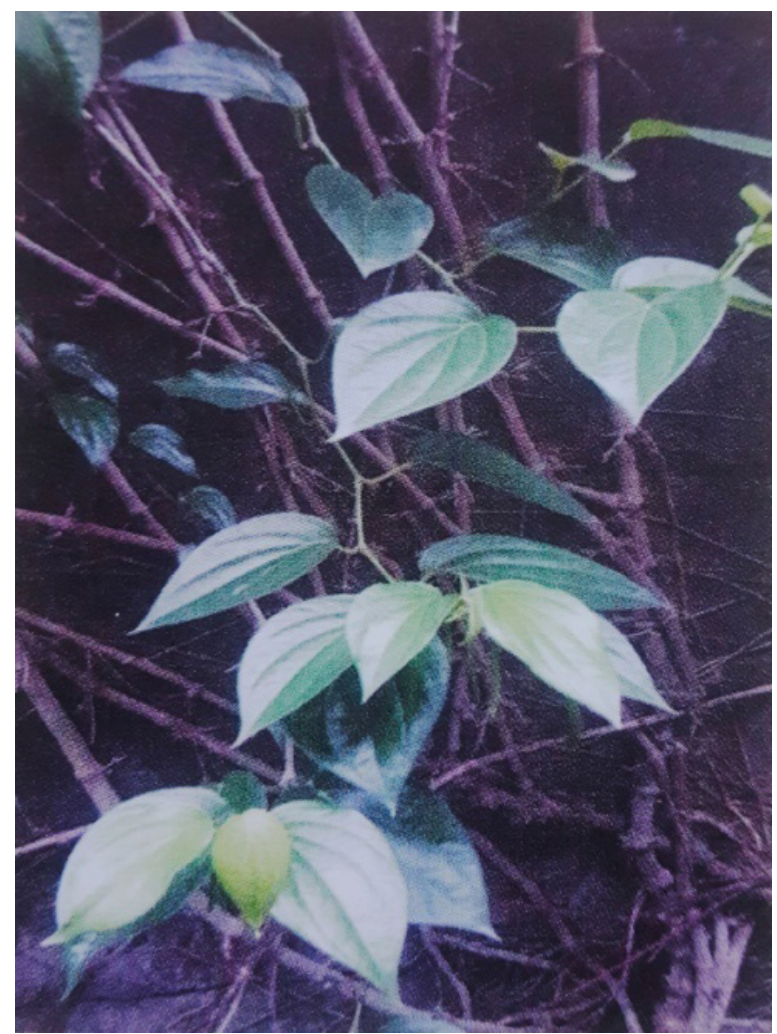

Fig. 1.Betel leaf. ${ }^{11}$

\section{METHODS}

This was a clinical experimental research with cross sectional approach. Spearman correlation test was used to determine the effect of herbal mouthwash on decreasing halitosis scores. The numbers of subject were 30 and obtained by quota sampling. Data collection was done by measuring initial and final halitosis score after rinsing with herbal mouthwash, using Tanita breath checker (Fig. 2). Parts of Tanita breath checker can be seen in figure 3. Tanita breath checker is an innovative palm-sized monitor that can detect and measure the presence of volatile sulfur compound (VSC) by displaying six levels of halitosis (Fig. 4). The six levels of halitosis score are: no odor, slight odor, moderate odor, heavy odor, strong odor and intense odor (Table 1). How to use Tanita breath checker is as follows. ${ }^{12}$

1. Pull the cover up, the sensor on the screen will turn on automatically. The number on the screen will count down 5-1. Gently shake the tool 4-5 times to remove the remaining odor and moisture.

2. The screen will display 'start', then breathe towards the sensor approximately $1 \mathrm{~cm}$ from the mouth until the tool beeps' (for about 4 seconds).

3. The halitosis score will be displayed after a few seconds. The sensor is closed again, then the tool will turn off automatically. 


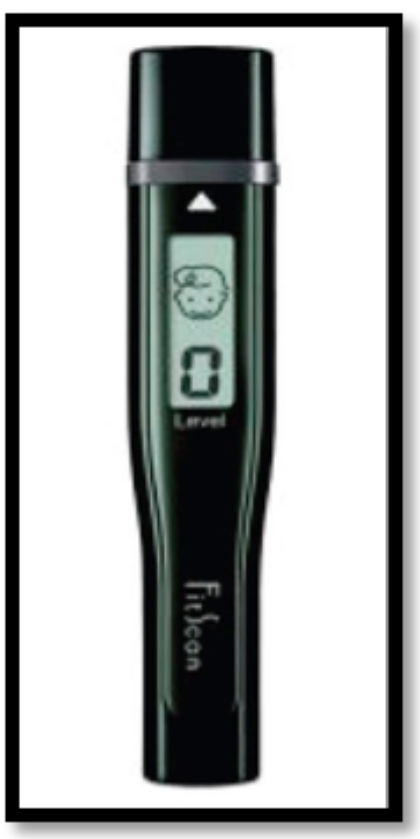

Fig. 2. Tanita breath checker. ${ }^{13}$

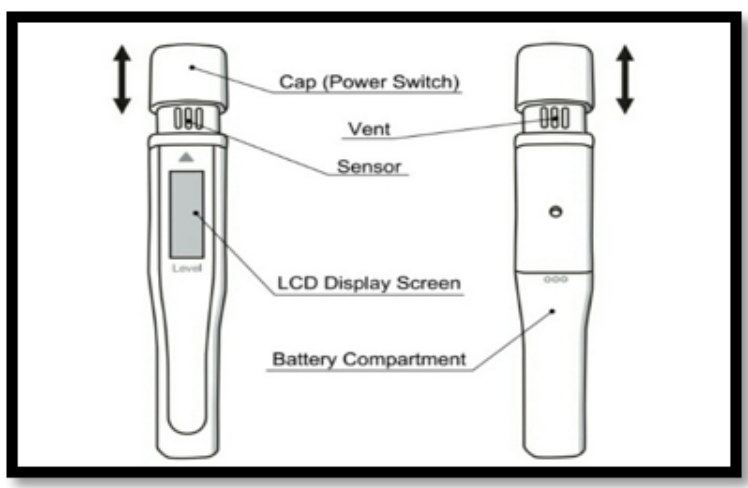

Fig. 3. Parts of Tanita breath checker. ${ }^{13}$

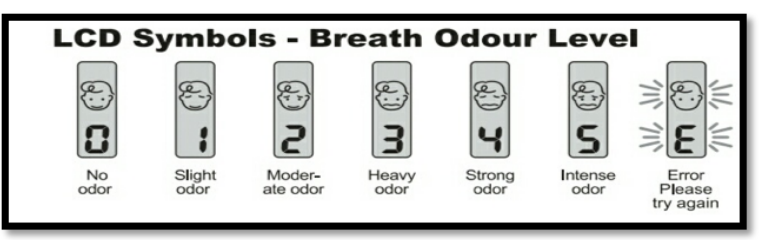

Fig. 4. LCD symbols. ${ }^{13}$

Table 1. Organoleptic measurement $t^{3,14}$

\begin{tabular}{cc}
\hline Halitosis score & Levels of halitosis \\
\hline 0 & no odor \\
1 & slight odor \\
2 & moderate odor \\
3 & heavy odor \\
4 & strong odor \\
5 & intense odor \\
\hline
\end{tabular}

\section{RESULTS}

The result of this study were:

Table 2. Subjects with halitosisin elderly based on gender

\begin{tabular}{ccc}
\hline Gender & Frequency & \% \\
\hline Male & 4 & 13,3 \\
Female & 26 & 86,7 \\
Total & 30 & 100 \\
\hline
\end{tabular}

Table 2 showed subjects with halitosis in elderly based on gender. It appears that from 30 subjects, it was found that in this study, most were female than male. Female subjects were $26(86.7 \%)$, while male were only $4(13.3 \%)$.

Before a statistical calculation is carried out, the normality of data testing is done first. The result from data normality test is to determine whether the data collected from 30 subjects have been distributed normally or abnormally, then the normality of the data is tested using the Saphiro-Wilk test. The data distribution is said to be normal if $p>0.05$. The results from this test had a value of $p=0.000$. It can be said that the data is distributed abnormally, so Spearman correlation test was done to determine the effect of herbal mouthwash on decreasing halitosis scores in elderly.

Table 3. Spearman correlation test (before and after gargling with betel leaf)

\begin{tabular}{cccc}
\hline Halitosis scores & Mean & SD & PValue \\
\hline Before & 2,0333 & 0,96431 & 0,000 \\
After & 0,8667 & 0,68145 & \\
\hline
\end{tabular}

The results of Spearman correlation test from table 3 showed halitosis scores before and after gargling with betel leaf had a value of $p=0.000$, because $\mathrm{p}<0.05$, it can be concluded that there were a significant differences between halitosis scores before and after gargling with betel leaf.

\section{DISCUSSION}

This research was carried out at Tresna Werdha Melania Social Institution, Jakarta in February 2018. Subjects were asked to rinse with a dose of $15 \mathrm{ml}$ of herbal mouthwash (betel leaf) for 30 seconds. This measurement is done by instructing the subjects to exhale slowly into the tube. The breath that has been exhaled into the tube is then evaluated and given an appropriate score from the organoleptic measurement table. ${ }^{14}$ 
The results showed a decrease in halitosis scores before and after gargling with herbal mouthwash (betel leaf). This significant decrease in halitosis score is indicated by the probability value (Pvalue) obtained from the Spearman correlation test result which is 0,000 less than the probability value of 0.05 .

The research explained that gargling with betel leaf was successful in reducing halitosis score, because it contained of essential oil. The essential oil in betel leaves consists of hydroxykavikol, kavibetol, estargiol, eugenol, methyleugenol, carvakrol, terpen, sesquiterpen, phenylpropan, and tannin. Of these chemical compounds, tannin (polyphenol compound) is known to have an antibacterial effect ${ }^{15}$. Essential oils consist of phenols and most are kavikol. Kavikol which gives a distinctive odor of betel leaf and has an antibacterial power five times stronger than phenol, so that the betel leaves have antioxidant and antifungal effect. ${ }^{16}$

Research conducted by Saraswati in 2011 states that betel leaf extract with concentration of $50 \%$, give a real different effect. This concentrationconsidered to be a minimal concentration of extract betel leaf which can inhibit bacteria. Essential oils from the batel leaf are able to fight gram-positive and gram-negative bacteria.Bacterial cell walls are mucopeptides, which are polymer complexes of amino acids, visible crosslinked by peptide chains that have pores to pass small molecules. Interaction of antibacterial compounds with mucopeptides causes damaged on bacterial cell walls. ${ }^{16}$

Research conducted on 30 elderly subjects at nursing home, intends to continue the research conducted by Nuniek in 2012 which states that the betel leaf boiled water is antibacterial against aerobic and anaerobic bacteria. This is due to the phenol content in betel leaves. Betel leaf is often used to treat halitosis. The chemical content in betel leaf is antibacterial because betel leaf contains essential oils. ${ }^{10}$

The results of this research also in accordance with research conducted by Ferlia Suci Ramadhani about the antibacterial content in betel leaves. Betel leaf has an antibacterial effect against Streptococcus mutans.It is known that Streptococcus mutans is a bacteria that plays a dominant role in the formation of dental plaque and dental caries, and it is one of the factors causing halitosis. ${ }^{17}$

Based on research that has been done, it can be concluded that the effect of gargling with herbal mouthwash (betel leaf) on halitosis in nursing home shows a significant decrease in halitosis scores. This is because betel leaf contains essential oils with the main component of essential oils consisting of phenols and their derivative compounds, namely kavikol. Kavikol has an antibacterial, antioxidant and antifungal properties.

Research on the effect of herbal mouthwash (betel leaf) against halitosis in elderly, conducted at nursing home, showed a good results. There was a significant decrease in halitosis scores in elderly after gargling with betel leaf.

\section{CONCLUSIONS AND RECOMMENDATIONS}

Based on the results of the study on the effect of gargling with betel leaf at nursing home, it can be concluded that there were a decrease in halitosis scores after gargling. The decrease in halitosis score is due to the betel leaf containing essential oils. The main component of essential oils consists of phenol and its derivative compounds, namely kavikol which has an antibacterial power five times stronger than phenol. So that betel leaf can be used as a herbal moutwash to treat halitosis in elderly. Based on the results of the research and analysis above, it is recommended that people especially the elderly begin to use herbal mouthwash (betel leaf) to reduce halitosis scores.

\section{REFERENCES}

1. Sutikno E. Hubungan antara Fungsi Keluarga dan Kualitas Hidup Lansia. Jurnal Kedokteran Indonesia. 2011; 2(1): 75 .

2. Dharmautama M, Koyama AT, Kusumawati A. Tingkat Keparahan Halitosis pada Manula Pemakai Gigitiruan. Jurnal Kedokteran Gigi Dentofasial. 2008; 7(2): 108-114.

3. Pintauli S. Masalah Halitosis dan Penatalaksanaannya. Dentika Dental Journal. 2008; 13(1): 75-77.

4. Etikkan S. Bad Breath. IOSR Journal of Dental and Medical Science. 2014; 13(6): 44.

5. Anwar AI. Penyebab dan Penanganan Halitosis. Jurnal Ilmiah dan Teknologi Kedokteran Gigi FKG UPDM(B). 2007; 4(1): 1-6.

6. Wijayanti A, Rahardjo A, Bahar A. Perubahan Parameter Halitosis Setelah Penggunaan Siwak (Salvadora persica) pada Santri Pondok Pesantren Tapak Sunan Usia 11-13 Tahun. J Dent Res. 2010; 17(2): 44.

7. Anastasia A, Yuliet, Tandah MR. Formulasi Sediaan Mouthwash Pencegah Plak Gigi Ekstrak Biji Kakao (Theobroma cacao L) dan Uji Efektivitas pada Bakteri Streptococcus mutans. Journal of Pharmacy. 2017; 3(1): 85.

8. Asdar. Bahan Kemoterapeutik Sebagai Pengontrol Plak dan Gingivitis. Journal of Dentomaxillofacial Science. 2007; 6(1): 2-3.

9. Fatimah S, Widodo, Adhani R. Perbandingan Skor Indeks Plak Sebelum dan Sesudah Berkumur dengan Air Rebusan Daun Sirih (Piper betle L) pada Ibu Hamil. Jurnal Kedokteran Gigi. 2017; 1(1): 95.

10. Nuniek NF, Nurachmah E, Gayatri D. Efektifitas Tindakan Oral Hygiene antara Povidone Iodine 1\% dan Air Rebusan Daun Sirih di Pekalongan. Jurnal Ilmiah Kesehatan. 2012; 4(1): 5-9.

11. Sasmito E. Imunomodulator Bahan Alami. Yogyakarta: Rapha Publishing; 2017: 111-113.

12. Singh M, Bansal P, Kaur S. The Association of Periodontal Disease with Oral Malodor Before and After Antibiotic Rinse Using FITSCAN ${ }^{\circledR}$ Breath Checker: A Clinical Study. Journal of The International Clinical Dental Research Organization. 2014; 6(2): 103-105. 
13. Corporation T. Tanita Breath Checker Instruction Manual [Internet]. Arlington Heights. 2010. Tersedia di: https://www.tanita.com

14. Tanwir F, Momin IA. Halitosis. Pakistan Oral and Dental Journal. 2011; 31(2): 305-307.

15. Hoppy D, et al. effect of Betel Leaf Extract Gel on Color Change in the Dental Enamel. IOP Conf Series: Journal of Physics. 2018.
16. Saraswati D. Pengaruh Konsentrasi Ekstrak Daun Sirih terhadap Daya Hambat Escherichia coli. Jurnal Health and Sport. 2011; 3(2): 331 - 333.

17. Ramadhani FC. Kandungan Antibakterial Dalam Daun Sirih; 2013. Tersedia di: https://www.scribd.com/ doc/147077685/kandungan-antibakterial-dalam-daunsirih 